\title{
Progress Report \#1 on the Materials Identification, Characterization and Evaluation Activity: Acquisition of Materials Data from the Exploratory Studies Facility
}

A. Meike

M. Spragge

February 1998

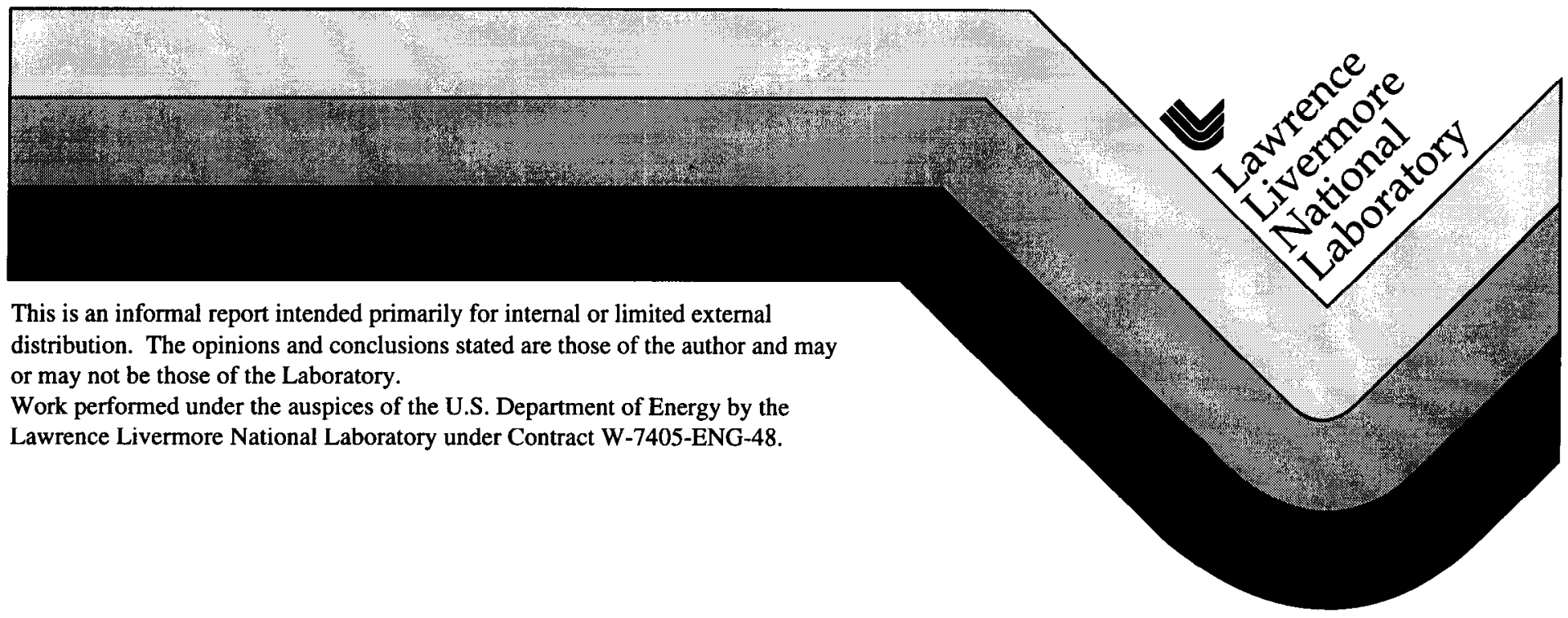




\section{DISCLAIMER}

This document was prepared as an account of work sponsored by an agency of the United States Government. Neither the United States Government nor the University of California nor any of their employees, makes any warranty, express or implied, or assumes any legal liability or responsibility for the accuracy, completeness, or usefulness of any information, apparatus, product, or process disclosed, or represents that its use would not infringe privately owned rights. Reference herein to any specific commercial product, process, or service by trade name, trademark, manufacturer, or otherwise, does not necessarily constitute or imply its endorsement, recommendation, or favoring by the United States Government or the University of California. The views and opinions of authors expressed herein do not necessarily state or reflect those of the United States Government or the University of California and shall not be used for advertising or product endorsement purposes.

This report has been reproduced directly from the best available copy.

Available to DOE and DOE contractors from the Office of Scientific and Technical Information P.O. Box 62, Oak Ridge, TN 37831

Prices available from (423) 576-8401

Available to the public from the National Technical Information Service

U.S. Department of Commerce 5285 Port Royal Rd., Springfield, VA 22161 


\title{
Progress Report \#1 \\ on the
}

Materials Identification, Characterization and Evaluation Activity :

Acquisition of materials data from the Exploratory Studies Facility

\author{
Annemarie Meike and Maura Spragge \\ Introduced Materials Task. \\ Yucca Mountain Project \\ Lawrence Livermore National Laboratory \\ Livermore, California
}

This Report satisfies the criteria for MOL 132 


\section{Table of Contents}

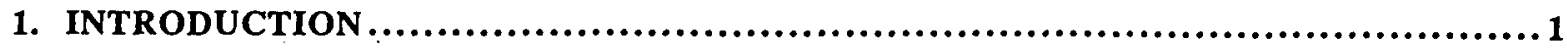

2. STATE OF DATA ACCESS...................................................4

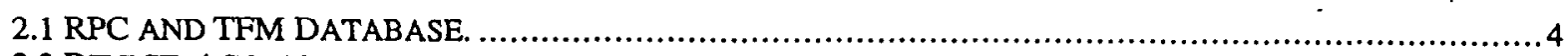

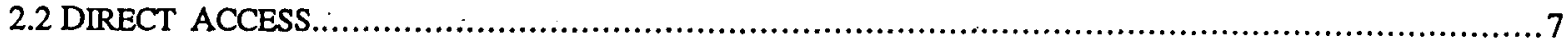

3. IDENTIFICATION OF MATERIALS IN THE ESF..............................8

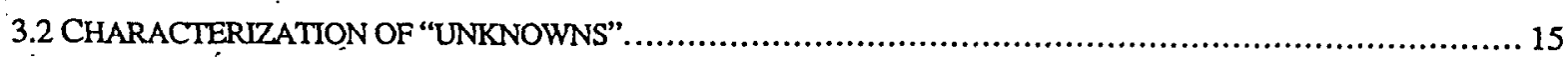

4. MODEL DEVELOPMENT...................................................... 8

4.1 EXAMINATION OF POTENTIAL REPOSTTORY DESIGNS. .................................................. 18

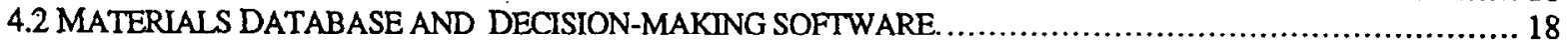

5. INTRODUCED MATERIALS TASK INTEGRATION............................. 9

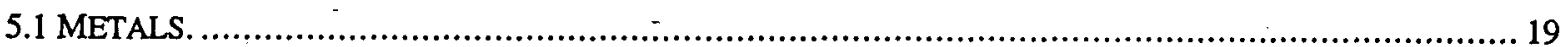

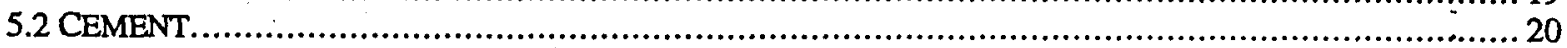

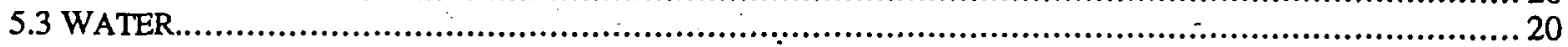

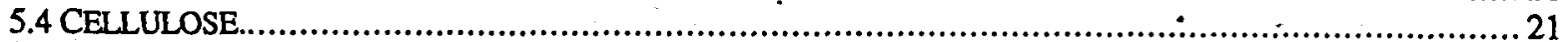

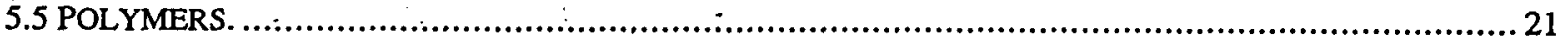

6. SUMMARY AND CONCLUSIONS............................................2 1

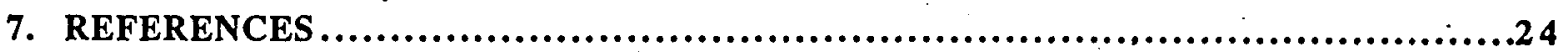

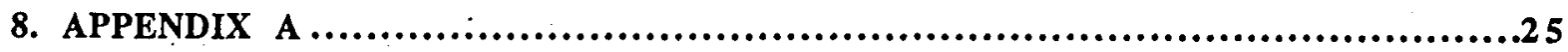




\section{Introduction}

This paper reports on the initial work within the Materials Identification, Characterization and Evaluation Sub-activity (Integration Activity) within the Introduced Materials Task (IMT) (WBS \# 1.2.3.12.5). The goals of this activity are twofold: 1) to identify and characterize types and usage of materials that are most likely to be introduced into a potential High Level Radioactive Waste (HLW) repository at Yucca Mountain, Nevada, as a result of its construction and operation and 2) to provide tools for the Integration Activity to evaluate the chemical impact on the repository based on information gathered from sources external and internal to the Introduced Materials Task by the Literature Survey Sub-activity (Integration Activity, IMT). Based on this information and assessment, the Integration Activity activates relevant activities within the Introduced Materials Task and provides information to other Tasks within the Yucca Mountain Project. For further information regarding the functions of the Materials Identification, Characterization and Evaluation Sub-activity, the Integration Activity and other Activities within IMT, refer to its Study Plan (Study Plan for Characterization Of The Effects Of Man-Made Materials On Chemical And Mineralogical Changes In The Post-Emplacement Environment SCP Sections 8.3.4.2.4.5) and relevant activity plans.

Work has been initiated within the Materials Identification Characterization and Evaluation Sub-activity the purpose of which is to provide the quantitative, compositional and location information regarding materials that may be used in a potential high level radioactive waste repository environment. This information provides the basis for chemical predictions within and external to the Introduced materials task. An iterative exchange between computer modeling and materials identification and evaluation will ultimately allow the Materials Identification Characterization and Evaluation Sub-activity to provide the most precise evaluations of materials and material combinations from the perspective of the long term chemical modification of a potential high level radioactive waste repository. environment. Thus it is clear that the purpose of the Materials Identification Characterization and Evaluation Sub-activity is to evaluate materials usage 
information in a way that provides a firm foundation to direct scientific and engineering decisions. Therefore the initial work in this area has been conducted from the point of view of building a framework upon which future work will be based. The intent of this report, then, is to demonstrate the utility of certain types of information from selected data sets. The data presented in this report represents a fraction of the specific compositional information that has been collected to date, and far more data will be needed in order to perform the purpose of this sub-activity. As will become clear, access to the data contained in the TFM database, where much of the information that is required should be archived, is not yet available. However, for the purpose of this first report, access to such data is less of a concern than it will be in the future. This first report emphasizes the recognition of classification systems, significant categories of materials, the assessment of reasonable limits to quantification, and the means to establish usable and significant mean values and deviations from the mean.

The aim of this initial effort has been to view the Exploratory Studies Facility (ESF) which constitutes a part of the Topopah Springs Loop tunnel presently being constructed at Yucca Mountain, as an analog for state-of-the-art tunnel engineering and construction, using the assumption that these methods in use, in conjunction with methods developed during the ESF excavation will approximate those used during the excavation and construction of the potential repository at Yucca Mountain. Specifically, this report describes initial efforts to document and characterize the quantities and usage of materials proposed for use in the ESF and to identify materials and quantities actually used in the tunnel. With respect to non-permanent materials the intent is to document quantity, usage, duration of emplacement and residual effects. This work steps beyond the report by West (1988), which documents materials usage in an earlier facility, with the intent to synthesize a large quantity of data into forms suitable for a variety of uses both internal and external to the Introduced Materials Task. We begin that synthesis effort by developing a framework for future use of this information. In addition to the identification of some quantities of materials used, their location within the tunnel, as well as their potential usage, this paper begins to outline useful categories of introduced materials and to provide a 
framework for the assessment of the variation between estimated and actual material usage and variations in usage through time as a function of application, regulations, and procedural developments.

The information retrieved by the Materials Identification Characterization and Evaluation Sub-activity is intended to determine the extent to which actual materials usage during construction and operation of an actual repository may be known or predicted, and will be used to determine ways to more tightly constrain bounding conditions for simulations of the materials and their chemical properties in such a repository environment. The evaluations of the Materials Identification Character-ization and Evaluation Sub-activity will be used in conjunction with existing data regarding materials, geological and hydrological properties for two purposes. The first purpose is to describe likely chemical interactions among the waste packages and natural and introduced materials, which can be used for assessment, evaluation and decision-making by repository and Yucca Mountain Project waste package design engineers. The second purpose is to predict chemical and hydrological behavior of the repository by Yucca Mountain Project chemists, material scientists, geochemists and hydrologists.

The first section of this report describes the acquisition of data from the project. This search, which can be treated as a case study of an effort to retrieve large amounts of archived information from YMP sources, is presented for two reasons. First, the future expectations for information retrieval by the Materials Identification Characterization and Evaluation Sub-activity are outlined. Second, it is hoped that this example may provide for improvements in archived information retrieval at some point in the future. The second section outlines the materials usage information that has been obtained to date, and presents initial assessments of the categories of information that are presently being retrieved and their utility. In the third section, decision analysis software that is presently under consideration for use by the Materials Identification Characterization and Evaluation Sub-activity is described. The final section summarizes important findings and maps the information retrieved to date onto other activities within the IMT. 


\section{State of data access.}

There are two general sources of data regarding materials usage in the ESF. The first source is records that are archived by the Yucca Mountain Project. The second source is direct inspection of ESF construction, engineering drawings and materials acquisition paperwork. The first section below discusses expectations of information that should be retrieved from archive sources within the Yucca Mountain Project based on YMP procedures. The second section discusses sources that have been developed within various agencies of the Yucca Mountain Project. This section also lays the groundwork for the notion of flexibility in materials usage during a. construction effort. This highlights the need for the Introduced Materials Task to not only be able to predict materials usage, but also to predict variability of material usage as a function of application and the probability of non-designed events.

\subsection{RPC and TFM Database.}

Initial efforts have been directed toward obtaining Tracers Fluid and Materials (TFM) usage reports in the pursuit of quantification of materials used in the excavation of the ESF and construction of support systems using procedures that seem to have been emplaced for that purpose. Current procedures and QA guidelines indicate that this documentation is a requirement of the processes involved in construction of the ESF. For example, according to the following excerpt from the latest Determination of Importance Evaluation (DIE )(Rev. 5):

QA records shall be made and provided in accordance with the TFM Procedure of all tracers, fluids, and materials consumed within the Topopah Spring Loop and associated operation and test support areas, including water, unrecovered wood, hydraulic fluids, fuels, oils, etc., and unrecovered spills. [ESFDR 3.2.1.4.B.1(b), 3.2.1.4.B.1(a), 3.2.1.4.F, 3.2.1.AA.2, 3.2.1.4.B.3, 3.2.9.4.A, 3.2.1.M, 3.2.1.M.1, 3.2.2.4.D].

A flowchart in YAP 2.8Q (attachment 9.2-YAP-2.8Q Flowchart)(Fig. 1) indicates that these reports are to be stored in the Records Processing Center (RPC) and the TFM Database, through the following processes with regard to the RPC:

Reporting of actual TFM Use/Removal:

5.5. 1.YMP Personnel informs RI of activity or accidental spill/release,

2. RI provides accident descriptions and any cleanup/removal to DI Manager,

3. Records data on TFM Report, and

4. Transmits TFM Report to RPC. 
5.5.1 Reporting of Planned TFM Use/Removal

5.5.1

\begin{tabular}{|c|}
\hline RI \\
\hline $\begin{array}{c}\text { Provides design, test } \\
\text { plan, or field activity } \\
\text { information to DI } \\
\text { Manager }\end{array}$ \\
\hline$\downarrow$ \\
\hline DI Manager \\
\hline If necessary, requests \\
additional information \\
\hline
\end{tabular}

5.2 TFM Evaluation

\& Approval

\begin{tabular}{|l|}
\hline \multicolumn{1}{|c|}{ DI Manager } \\
\hline - Conducts a DIE \\
- Transmits DIE \\
documentation to \\
RPC, RI, \& TFM \\
DBA
\end{tabular}

5.3 Reporting of Actual TFM Use/Removal

5.3.1

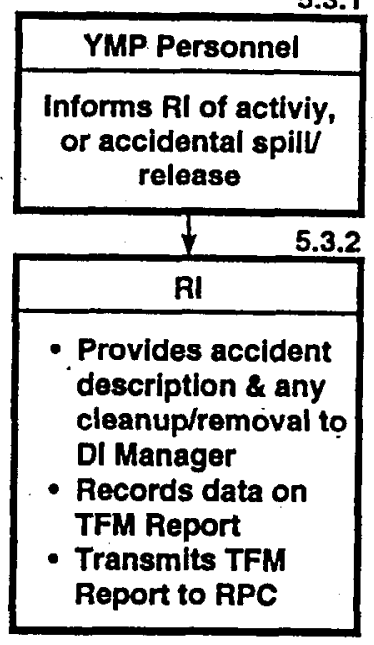

\section{LEGEND}

DBA - Database Administrator

DI Determination of Importance

DIE Determination of Importance Evaluation

RI Responsible Individual

RPC Records Processing Center

TFM Tracers, Fluids, \& Materials

YMP Yucca Mountain Site Characterization Project
5.4 Reporting of Design, Test Plan, \& Fleld Activity Changes

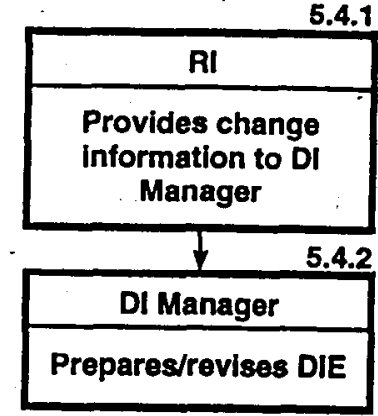

5.5 TFM Database Management

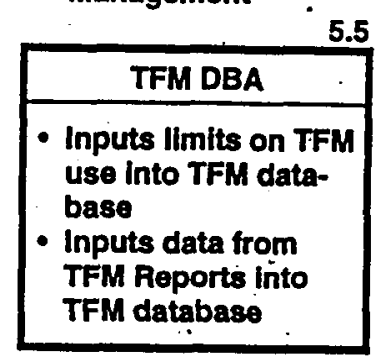

Figure 1. A flowchart reproduced from YAP 2.8Q (attachment 9.2-YAP-2.8Q) indicates that TFM reports are to be stored in the Records Processing Center (RPC) and the TFM Database. 
The RI represents the "responsible individual" and DI represents "determination of importance". Table 1 further details reporting practices that should allow the Materials Identification and Evaluation Sub-activity to retrieve data in the future.

With regard to the TFM database:

5.5. TFM Database Management -TFM DBA (database administrator)

1. Inputs limits on TFM use into TFM database, and

2. Inputs data from TFM Reports into TFM database.

A considerable amount of time has been expended to recover TFM usage reports that should be readily available. According to the Database Administrator (DBA), the means of recovering these records is through the GENISES network using databases stored on compact disk (CD). At present, we do not have access to these databases. However, a recent-status report ("Tracers Fluids and Materials (TFM) Status Report for the Period Jan. 1995-March 1995") suggests that the data we require may not yet be entered into the:TFM database. - The quotations below obtained from the April 1, 1995 Tracers Fluids and . Materials (TFM) Database status report for the period January 1995 - March 1995 reveals some of the complexities related to the present ability to access TFM reports.

The TFM database currently contains two data sets. The first set consists of the original TFM data compiled by Los Alamos National Laboratory, and entered into the TFM system provided by Computer Applications Group, Inc. As of March 31,1995 , these data have not been processed, compiled, and verified inder an approved QA procedure... The second data set consists of data received from data providers after the transition from Los Alamos to EG\&G/EM. These data are currently being processed into the TFM database.

YAP-2.8Q... identifies the attributes for approved and "as-built" TFM data. This document will require an extensive redesign of the TFM database... All data that has been submitted to the TFM database up to this date will need to be reformatted to fit within the revised TFM System which corresponds to the new TFM forms described in the TFM Procedure.

The communications software required to access GENISES (TCPIP) has not been installed on the YMP communications backbone. Access to the TFM database will not be possible without this software. 
Table 1. Guide to TFM Reporting

\begin{tabular}{|c|c|}
\hline What is reportable & All TFM use/removal ${ }^{1}$ \\
\hline When & Prior to the start of testing, facility construction, or other field activity ${ }^{2}$ \\
\hline Responsible parties & RI, DI, MMP personnel, TFM database administrator (TFM DBA) ${ }^{3}$ \\
\hline Specifics reported ${ }^{2}$ & $\begin{array}{l}\text { 1. Description of planned activities and facilities, location, } \\
\text { start and completion dates } \\
\text { 2. Data on planned TFM use/removal, using TFM report } \\
\text { 3. Description of planned TFM storage } \\
\text { 4. Description of chemical compositions of fluids not commonly known, or } \\
\text { reference to information } \\
\text { 5. Description of expected and potential accidental composition or phase } \\
\text { changes } \\
\text { 6. Description of any mixing of fluids with other fluids (excluding with or } \\
\text { between naturally occurring fluids and materials) } \\
\text { 7. MSDS's for any TFM's for which they exist } \\
\text { 8. Information on environmental safety and health requirements, where } \\
\text { applicable. } \\
\text { 9. TPP and JP numbers and titles, ESF Design Package numbers and titles, and } \\
\text { Site Characterization Plan Baseline number, where applicable. } \\
\text { 10. RI's names and organizations, and identification of respective } \\
\text { responsibilities. }\end{array}$ \\
\hline Exemptions & $\begin{array}{l}\text { Temporary use of the following items (removed from site prior to licensed } \\
\text { repository operation) } \\
\text { 1. Articles for personal use } \\
\text { 2. Clothes } \\
\text { 3. Food \& drink for human consumption } \\
\text { 4. Fluids used for normal use of tools, equipment, and vehicles, w/ the } \\
\text { exception of fluids used underground. } \\
\text { 5. Furniture } \\
\text { 6. Instrumentation } \\
\text { 7. Naturally occurring fluids (including water) and materials, except water } \\
\text { that is pumped or hauled by truck } \\
\text { 8. Personal protective equipment } \\
\text { 9. Tools (motorized or not) } \\
\text { 10. Utensils for personal use } \\
\text { 11. Vehicles (motorized or not) for the transport of personnel and/or TFM's }\end{array}$ \\
\hline General Instructions ${ }^{4}$ & $\begin{array}{l}\text { Prepare a separate TFM report for: } \\
\text { 1. Planned TFM use } \\
\text { 2. Planned TFM removal } \\
\text { 3. Actual TFM use (including accidental spills/releases) } \\
\text { 4. Actual TFM removal (including spill cleanup and remediation }\end{array}$ \\
\hline
\end{tabular}

1 YAP-2.8Q 3.6, Reportable TFM Use/Removal.

2 YAP-2.8Q 5.1, Reporting of Planned TFM Use/Removal.

3 YAP-2.8Q 4.0, Responsibilities.

4 XAP-2.8Q; attachment 9.4. 
And from memo (YMSO-95-025) dated February 1, 1995 to Peter

Hastings from Jim Beckett:

We are currently processing information provided from the M\&O DIE group into the TFM database. The system captures approved type, quantity, and condition TFMs from the DIE package. As "as-built" information is provided, the system compares the approved quantity or volume against the used quantity...

Currently, we are receiving DIEs with text information such as "To be measured" etc. ... We are also receiving limits which are described as "see attachment" or Refer to requirements $11,12,15$ " etc. However, the values are not provided with the submittal documentation... I would also like to take this opportunity to let you know that I have not received an "as-built" form in over three months.

If materials usage data has not been entered into the TFM database, we will require access to the original records.

Once the TFM CD is received, some additional time may be required to become familiar with the capabilities of the software. This expectation is supported by the experience of records retrieval from the Records Process Center (RPC). Although the RPC responded immediately to requests for information, the reports have not yet been recovered for what appear to be two reasons. First, searches are conducted by report number or title word, which limits the ability to access information by subject. To date, searches have exposed a preponderance of procedural documents and a few actual usage reports. Second, there is a significant time lag between the logging of a . TFM report into the system and its entry into the RPC as a complete record. The considerable time commitment involved in sorting retrieved reports to obtain information via this route is being continued through the RPC.

\subsection{Direct Access.}

\subsubsection{M\&O companies.}

A partial list of Yucca Mountain Project personnel who were contacted directly for access to records, documents (including reports, engineering drawings, inventories and manifests) or other potential contacts in an effort to recover materials usage data is as follows:
a. D. Rogers, $\mathrm{M} \& \mathrm{O} / \mathrm{MK}$
b. J. Beckett, EG\&G/EM/RSL
c. D. Kovach, ESF TCO 
d. P. Hastings, M\&O/Duke

e. N. Bartley, $\mathrm{M} \& \mathrm{O} /$ Duke

f. K. Jerome M\&O/TRW

g. G. Houston, $M \& O / T R W$

h. D. Piniol, M\&O/TRW

i. C. Houston, $\mathrm{M} \& \mathrm{O} / \mathrm{TRW}$

.j. B. Bush, T\&MSS

As a result of these contacts, we have obtained a package of 15 drawings of construction plans and details, which represent some of the construction materials and systems emplaced in the tunnel. These drawings have been acquired within the last week. Therefore, a full assessment of the information contained in these drawings will be presented in a future report for this subactivity.

\subsubsection{ESF Survey}

A preliminary survey of the ESF from the portal to within forty feet (the length of the tunnel boring machine) of the excavation was conducted to note construction features that are not evident from the engineering drawings, to develop a greater sense of the flexibility in materials usage that must be an inherent part of any construction effort, and to note the impacts of various changes in external factors over time. These factors are discussed in Section 3.2 as the beginning phase of an attempt to narrow the bounds of unknown materials and materials usage in the potential Yucca Mountain Repository.

\section{Identification of materials in the ESF.}

\subsubsection{Monthly Reports.}

Monthly reports, issued by Los Alamos National Laboratory exploratory studies facility field test coordination office (ESF TCO), provide the following information in an informal format. In the starter tunnel and subsequent tunnel segments, excavation progress, position of the TBM (where applicable), and ground control methods and types of material used are described. Monthly water usage and total water usage to date are provided. Further details regarding water usage are discussed 'below in the Specific Materials Usage Section (3.1.3). 
No other quantities of materials are given in the ESF TCO monthly report. The progress of the excavation of alcoves is reported with reference to current depth.

\subsubsection{TFM Reports}

1993 TFM reports of estimated materials usage were obtained two years ago for the ESF North Portal starter tunnel, the surface pad and the box cut (see Appendix A). The estimated usage reports are useful for gross estimates of quantities of materials to be used, and also assessments of whether the material is temporary or permanent. For example, the materials usage estimates for the box cut include ground supports, for which temporary ground support have been distinguished from the rest. To date, the TFM Reports of actual usage appear to be unavailable (see Section 2.1).

It is clear from these few reports that materials usage varies as a function of constructional purpose. For example, it is more useful to distinguish estimates of material usage for alcoves from the north ramp starter tunnel and other easily distinguishable tunnel zones, rather than calculate an average total usage for the entire Topopah Springs Loop tunnel. For example; Fibercrete ${ }^{\mathrm{TM}}$ was used in large quantities in the North Portal for consolidation purposes. In contrast, deeper into the tunnel the cementitious material present is primarily in the form of concrete inverts. Therefore, as it is gathered in addition to compositional information, materials information will be categorized according to location in order to facilitate future predictions of materials usage based on this data.

\subsubsection{Specific Materials Usage.}

The materials usage data regarding specific materials is discussed below in order to highlight features of the reporting procedures that affect the ability of the Materials Identification, Characterization and Evaluation Sub-activity to gather information and thus its ability to predict usage of that material in the future. 


\subsubsection{Water.}

The weekly ESF TCO report provides information on the amount of actual water use per week and the cumulative amount of water used. However, the term "water use" is actually used to specify the quantity of water transported into the tunnel. These reports do not specify how much water was removed with the muck and how much was consumed or lost in the process of excavation and construction. The-water usage limit specified in the DIE of no more than 7.4 cubic meters of water per linear meter of tunnel excavated has not been exceeded (Fig. 2). An average of the total amount of water used to date is $2.47 \mathrm{kl} / \mathrm{m}$. Figures $3 \mathrm{a}$ and $\mathrm{b}$ illustrate a more detailed week by week analysis of water usage. Figure $3 a$ shows that to a first approximation, water usage mirrors excavation progress. From Figure $3 b$ it is clear that an normal weekly amounts of water usage of between 2 and $4 \mathrm{kl} / \mathrm{m}$ are punctuated by events of large water usage. The Materials Identification, Characterization and Evaluation Subactivity intends to relate these events to known functions in order to predict water usage more accurately. QA controls in place (Table 2) indicate

\section{Water Input v. Tunnel Progress}

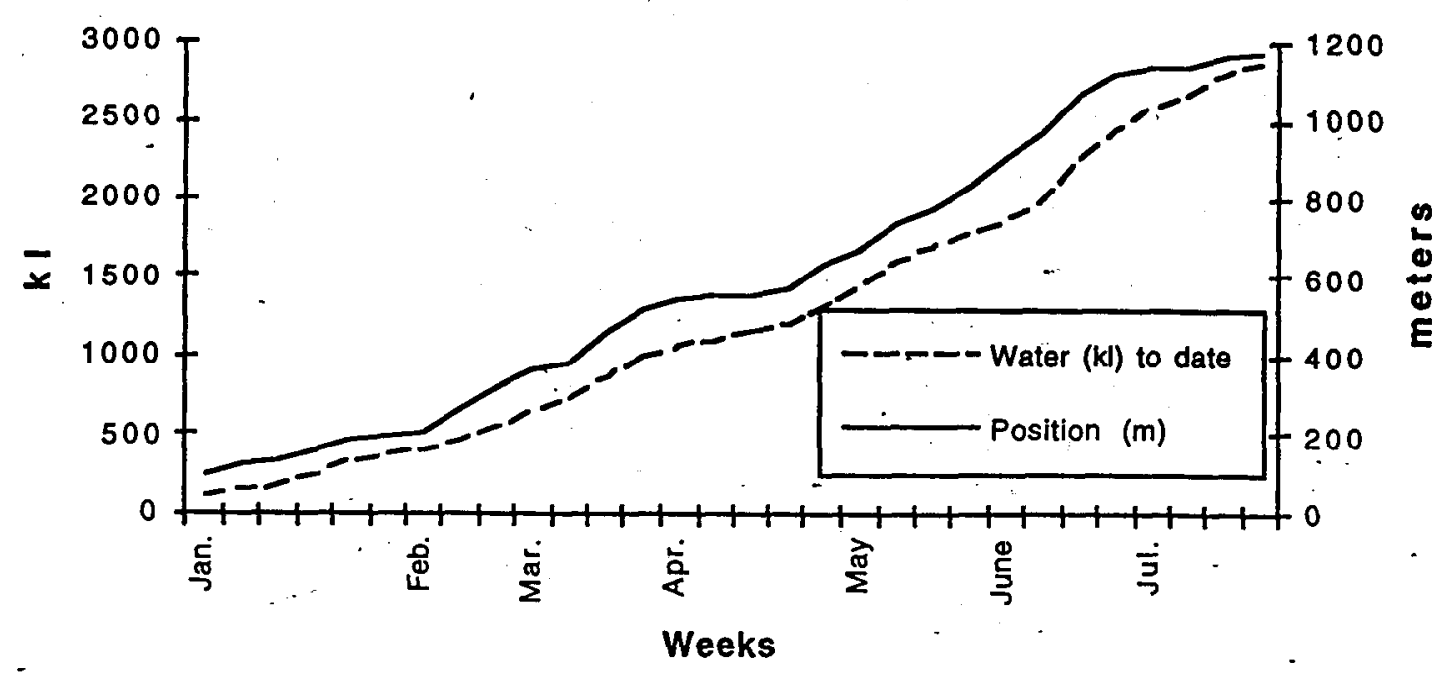

Figure 2. Total water usage and total meters excavated are plotted as a function of time. It is clear that the limit specified in the DIE of no more than 7.4 cubic meters of water per linear meter of tunnel excavated has not been exceeded. Total water usage to date averages roughly $2.47 \mathrm{kl} / \mathrm{m}$. 


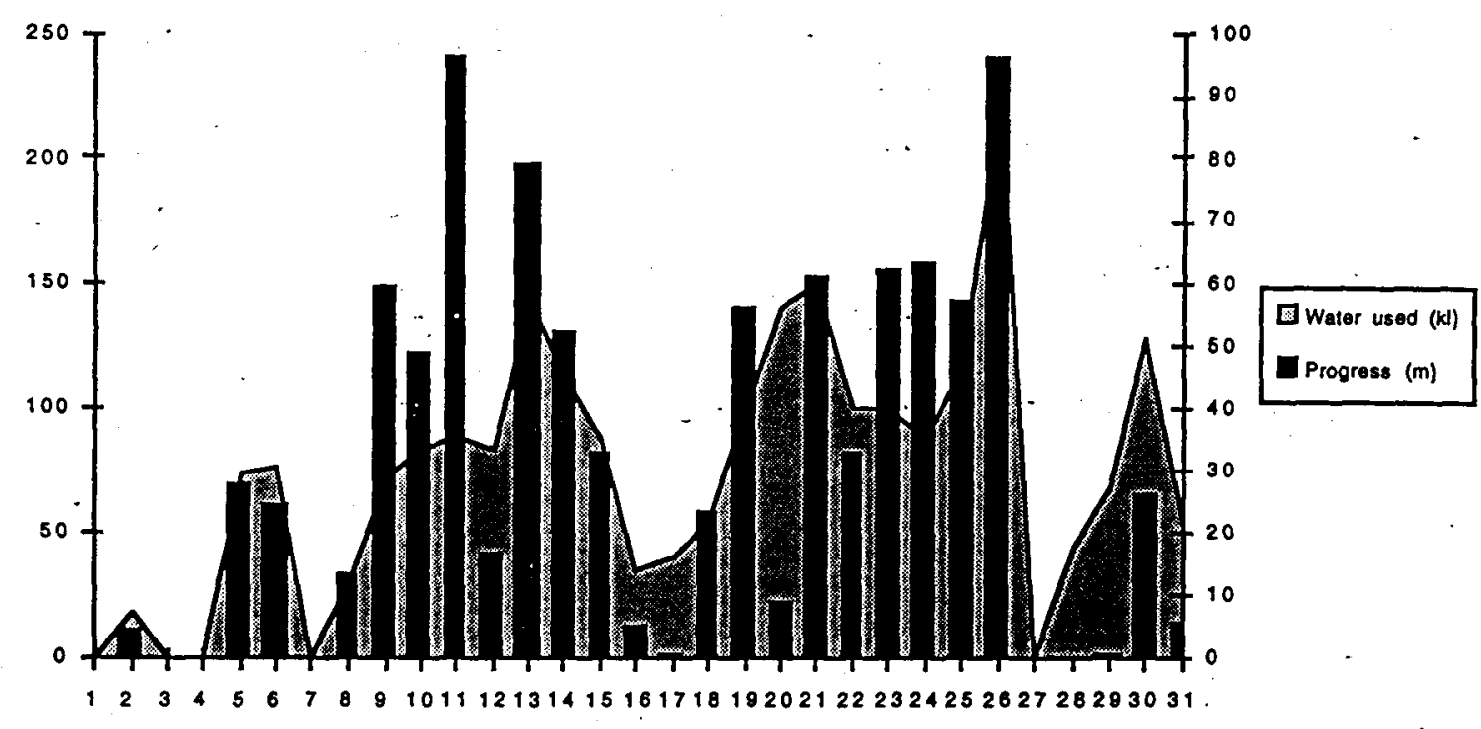

a

Weekly Water Usage $1995(\mathrm{kl} / \mathrm{m}$.

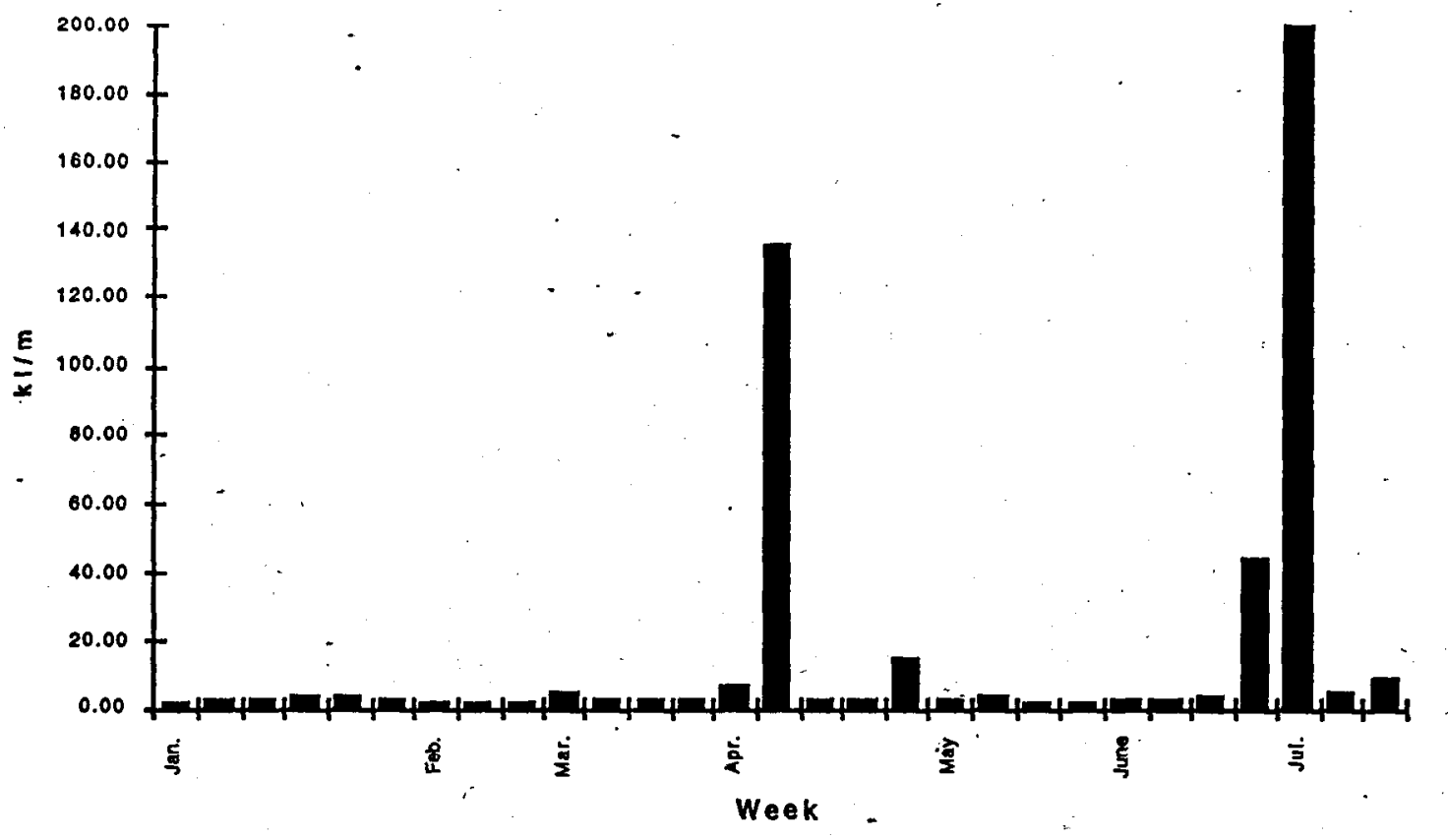

$\mathbf{b}$

Figure 3. a) A plot of weekly water usage and weekly excavation progress as a function of time suggest a strong correlation between water usage mirrors excavation progress. b) A plot of water usage in $\mathrm{kl} / \mathrm{m}$ as a function of time demonstrates that an average amount of water usage of between 2 and $4 \mathrm{kl} / \mathrm{m}$ is punctuated by episodes of large water usage. 
that records should specify, in addition to quantities of water introduced, the quantities of water removed (e.g. with muck), lost or consumed to a greater level of detail.

Table 2. ESF water controls.

\begin{tabular}{|c|c|c|c|}
\hline $\begin{array}{l}\text { WATER REPORT } \\
\text { REQUIRED }\end{array}$ & $\begin{array}{c}\text { TFM } \\
\text { REQUIRED }\end{array}$ & APPLICATION & LIMT \\
\hline Water In ${ }^{1}$ & Yes $^{1}$ & Any" & No \\
\hline Water Out & Yes $^{1}$ & Any" & No \\
\hline $\begin{array}{l}\text { Water Used } \\
\text { (removed) }^{1}\end{array}$ & Nob. & $\begin{array}{l}\text { - conveyor, TBM and } \\
\text { mechanical excavator dust } \\
\text { control } \\
\text {-wetting of muck piles }\end{array}$ & No \\
\hline List of Uses 1 & No & Alli $^{2}$ & NA \\
\hline $\begin{array}{l}\text { Water Consumed } \\
\text { (lost) }\end{array}$ & $\overline{Y_{e s}^{2}}$ & $\begin{array}{l}\text {-geologic mapping } \\
\text {-mixed } w / \text { cementitious } \\
\text { materials }{ }^{c}\end{array}$ & $\begin{array}{l}S \text { an average of } 7.4 \mathrm{~m}^{3} / \text { linear } \mathrm{m} \text { : } \\
\text { of tunnel excavated.d }\end{array}$ \\
\hline \multicolumn{4}{|c|}{$\begin{array}{l}\text { except personal consumption } \\
\text { b spill control limits are judged adequate to limit the potential for leakage from the conveyor to significantly impact the } \\
\text { accuracy of the TFM reporting, however, data obtained from the water balance on recovered water should be used to adjust } \\
\text { water lost reports } \\
\text { c beyond the PTn-TSw1 contact; water mixed w/cementitious materials above the lower limit of the PTn is not considered } \\
\text { lost } \\
\text { dshall be verified a minimum of once per shift }{ }^{3}\end{array}$} \\
\hline
\end{tabular}

\subsubsection{Diesel fuel and exhaust.}

Diesel fuel usage reports which include as a minimum, the type of engine or equipment used, the volume of fuel used, and the number of hours the equipment was operated are a QA requirement, specified in DIE (Rev. 5) Diesel Requirement 13.1.27. We expect that, when obtained, these data in addition to ventilation and other data will be used to estimate exhaust products.

Diesel fuel and other spills are to be recorded on incident reports. We note that spills of under a certain amount do not require an incident report. Future work in this area will include obtaining incident reports, verifying reporting minimums and determining whether those reporting minimums have changẹd over time.

\footnotetext{
${ }^{1}$ DIE, 13.1.19, Water Balance

2 DIE 13.1.17, Water TFM Report

${ }^{3}$ DIE 13.1.16, Water Controls
} 


\subsubsection{Rack bolts.}

Five types of rockbolts are presently available for use in the ESF (Table 3). Of these only the long Swellex ${ }^{\mathrm{TM}}$ and Williams Hollow Core ${ }^{\mathrm{TM}}$ and Solid \#8 Threaded rockbolts are noted on the engineering diagrams. Thus, better estimates of rockbolt usage will be obtained from TFM actual usage reports and direct observation of the tunnel.

\subsubsection{Concrete and Grout.}

\subsection{Rock bolt grout.}

The grout composition for the Williams ${ }^{\mathrm{TM}}$ rockbolts is stipulated by a "Transmittal of Shop Drawings, Equipment Data, Materials Samples, or Manufacturer's Certificates of Compliance (SDT)" (Form \#AP-5.26) dated 16 January, 1995. It stipulates that the grout is type E-1 $(\mathrm{K})$ and specifies the brand Wil-X-Cement ${ }^{\mathrm{IM}}$, thixotropic grout. A water/cement ratio (w/c) of 0.4 by weight is stipulated, not to exceed 0.5. It should be noted, however, for the purpose of establishing water introduced into the repository environment, that the mixing of concrete is not exact. According to the SDT, the actual amount of water is left to the operator's discretion, as it needs to be. The operator must assure that $\mathrm{w} / \mathrm{c}$ does not exceed 0.5 , even though $5 / 6$ of the total amount of water to be used is added to the tank before the grout is added.

Table 3. Rockbolt types and associated materials

\begin{tabular}{|l|l|l|}
\hline Rockbolt Type & $\begin{array}{l}\text { Explicitly referred } \\
\text { to on engineering } \\
\text { diagrams }\end{array}$ & Associated Materials \\
\hline $\begin{array}{l}\text { Super Swellex } \\
\text { (long and short) }\end{array}$ & $\begin{array}{l}\text { long only } \\
(3000 \mathrm{~mm} \text { nom. })\end{array}$ & $\begin{array}{l}\text { water is applied at a regulated pressure to } \\
\text { inflate the bolt }\end{array}$ \\
\hline $\begin{array}{l}\text { Solid \#B Threaded } \\
\text { long and short) }\end{array}$ & $\begin{array}{l}\text { long only } \\
(3000 \mathrm{~mm} \text { nom) }\end{array}$ & $\begin{array}{l}\text { grouted into place. } \\
.\end{array}$ \\
\hline Williams ${ }^{\text {TMHollow Core }}$ & $(3000 \mathrm{~mm}$ nom) & grouted. \\
\hline Split Set & no & unknown \\
\hline
\end{tabular}

'BABEABOOO-01717-2100-40157-01.

'per. comm. Eugene Pokorny 
Table 4. Chemical composition of rockbolt grout, average Type $\mathrm{K}$ shipment, analysis of May 1994 supplied by the manufacturer, Southwestern Portland Cement Co.

\begin{tabular}{|l|c|}
\hline Chemical Composition & Percent \\
\hline Silicon Dioxide $\left(\mathrm{SiO}_{2}\right)$ & 18.7 \\
\hline Aluminum Oxide $\left(\mathrm{Al}_{2} \mathrm{O}_{3}\right)$ & 5.5 \\
\hline Ferric Oxide $\left(\mathrm{Fe}_{2} \mathrm{O}_{3}\right)$ & 2.9 \\
\hline Magnesium Oxide $(\mathrm{MgO})$ & 4.0 \\
\hline Sulfur Trioxide $\left.\mathrm{SO}_{3}\right)$ & 5.4 \\
\hline Loss on Ignition & 1.9 \\
\hline Insoluble residue & 0.2 \\
\hline Tricalcium Silicate & $*$ \\
\hline Tricalcium Aluminate & $*$ \\
\hline Alkalis, Eqv. $\mathrm{Na}_{2} \mathrm{O}$ & $*$ \\
\hline
\end{tabular}

"Not required to specify.

\subsection{Shotcrete}

The composition of shotcrete obtained from the manufacturer, via the ESF : construction contractor is given in Table 5.

\subsection{Invert}

Concrete inverts will be more easily quantified and characterized than some of the other materials, due to their size, shape, pre-casting and deliberate emplacement. Each invert section in the ESF is $4 \mathrm{ft} . \times 10 \mathrm{ft}$. in plan view and

weighs 5 tons. A cross-sectional sketch is of the starter tunnel is illustrated in Figure 4. Two cross-sections of the invert are shown. We have not established the composition of the cementitious grout for this concrete. However it has been established that the inverts are reinforced with rebar. Gravel sources are yet to be verified, but appear to be one or more of the following: Wolfenstein (Pahrump) WMK (Las Vegas) and Nevada Ready Mix (Location not yet identified).

Materials used, and the mass of the inverts will be determined by using information from mechanical designs and interviewing fabricators. Samples of the invert material will be taken as necessary. Direct observation of their use in the 
tunnel and TFM Reports of actual use will provide the actual number of inverts in the tunnel.

Table 5. Composition of wet process shotcrete, design mix \#501, supplied by Kiewit/PB, Yucca Mountain project.

\begin{tabular}{|l|l|}
\hline Type II Cement' & $775 \mathrm{lb} / \mathrm{cu}$ yd \\
\hline Water & $352 \mathrm{lb} / \mathrm{cu}$ yd (42.3 gal) \\
\hline $\mathrm{CA}^{2}$ (Wulfenstein) & $1261 \mathrm{lb} / \mathrm{cu}$ yd \\
\hline FA $^{3}$ (Wulfenstein) & $1539 \mathrm{lb} / \mathrm{cu}$ yd \\
\hline Master Builders Polyheed (WRA) & $93 \mathrm{oz} / \mathrm{cu}$ yd \\
\hline Master Builders QSL-100 Shocrete & approx. 48-50 lb/cu yd \\
\hline Accelerator & n.d. \\
\hline Water/ Cement Ratio & 0.45 \\
\hline $\begin{array}{l}\text { 'Supplier: Riverside Cement. } \\
\text { 'Acronym not yet verified. } \\
\text { 'Fly ash. } \\
\text { 'Not determined. }\end{array}$ & \\
\hline
\end{tabular}

\subsection{Characterization of "unknowns".}

\subsubsection{Flexibility inherent in engineering drawings.}

As for most working designs, the ESF tunnel design drawings allow a certain amount of freedom in materials and construction. The architect/engineer designates and approves the category of ground support to be used as well as allowing for modifications to be made to the ground support category requirements. The contractor decides, based on field conditions and experience, the actual materials used within the limits specified by the architect/engineer.

\subsubsection{Construction features not evident in engineering drawings acquiree to date.}

- In evidence were materials such as an excelsior-like substance used for fill, polymer material between concrete invert segments (Fig. 4), short rock bolts and blasting curtains composed of rubber tires. The use of these materials underscores the need of the Materials Identification Characterization and Evaluation Sub-activity to 
compare the engineering drawings and requests for material usage to the actual asbuilt drifts and actual usage reports.

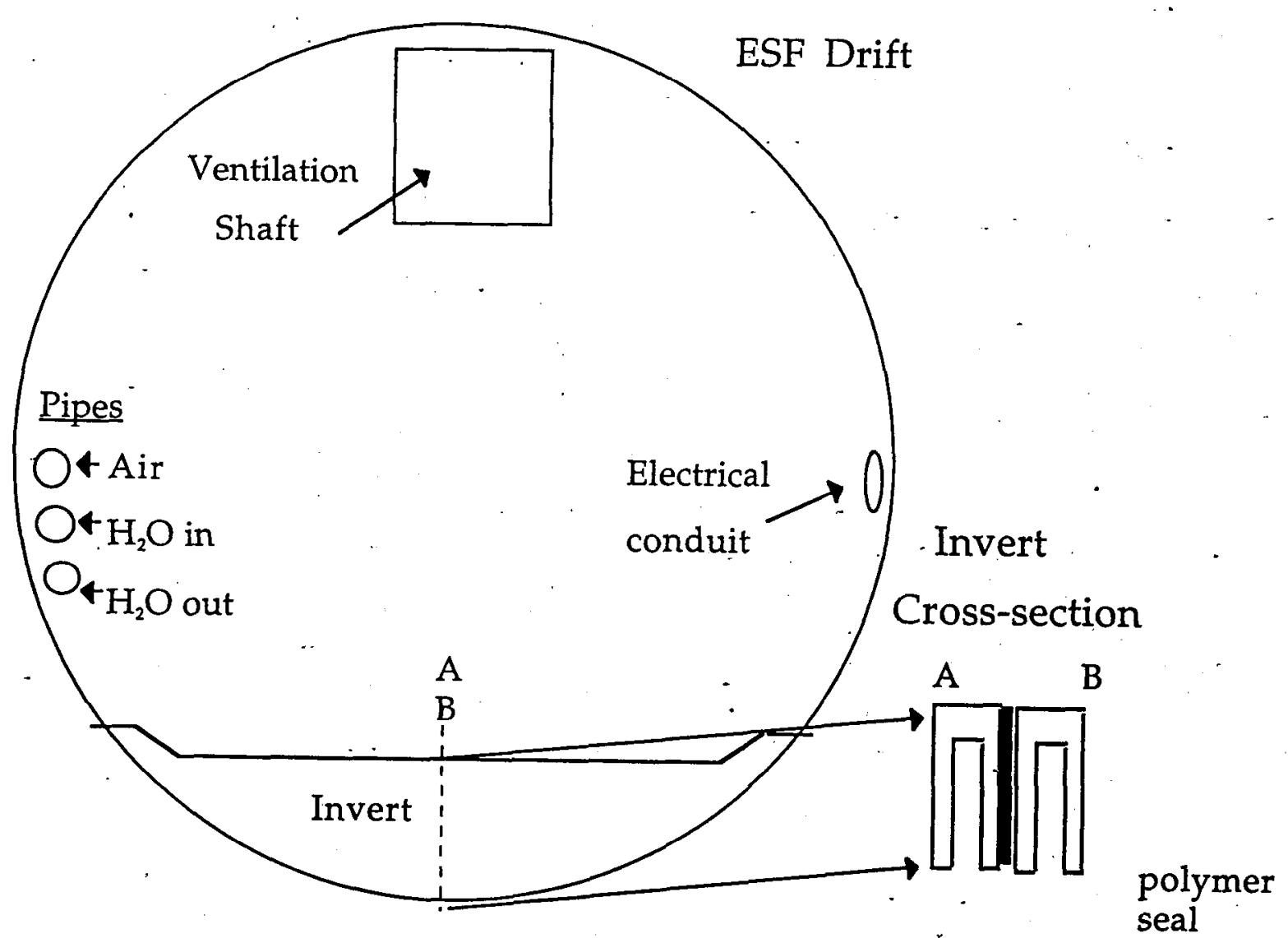

Figure 4. Schematic view (not to scale) of invert placement illustrates the placement of some materials. The shape of the invert is illustrated in tunnel cross-section, and the invert cross-section parallel to the tunnel axis.

\subsubsection{Rock Falls}

Ground support is divided into categories, but the category used is up to the discretion of the contractor with the approval of the architect/engineer. For example, rockbolt pattern spacing is approximate and may be adjusted and/or rockbolt usage increased by the contractor to address the geologic features encountered. Since rockbolts are required to be reported as actual TFM used, records of quantities and locations are expected. It is not yet clear whether the quantities and identities of 
related materials (such as grout and water) will be reported in such a way that it can be related to rock bolt emplacement.

\subsubsection{Large Fractures}

Large fractures that are encountered necessitate the use of copious amounts of a variety of materials for stabilization. Observation of the tunnel revealed some of the materials used to be sand, excelsior, and lumber. Lengths of $4 \times 4$ in. wood pieces (Fig. 5) and metal slabs have been used as fault fillings. Although the location and severity of the rock fall may be unpredictable and therefore cannot be included in a design, rock falls are a normal phenomenon to be anticipated when excavating. In order to better constrain estimates of materials usage it will be necessary to monitor the use of steel pieces, wood $4 \times 4$ 's and other materials such as sand and excelsior that are used during the consolidation of compromised rock. We expect that although the materials used for fill and support may not have been incorporated into the estimated (planned) usage TFM Report, the actual quantities and locations will be included in the TFM reports of actual use.

\subsubsection{TBM gripping \& emplacement enhancement}

The TBM must grip the ground and remain stationary in order to exert enough force against the face of the tunnel to actually cut the rock. In areas where there are voids in the inside diameter of the tunnel fill material (fibercrete, shotcrete, sand, and cement-water slurry) is introduced to provide a support surface for the grippers of the machine.

\subsubsection{External factors.}

This survey of materials usage has revealed a few external factors that have an impact on materials usage and the ability to monitor materials usage over time.

\subsubsection{Impact of changes in policy through time.}

Some restrictions governing the use of certain materials (e.g. diesel fuel) and/or amounts of those materials (e.g. Fibercrete ${ }^{\mathrm{TM}}$ ) have been either added or deleted as tunnel excavation has progressed. As a result, we intend to define tunnel zones by 


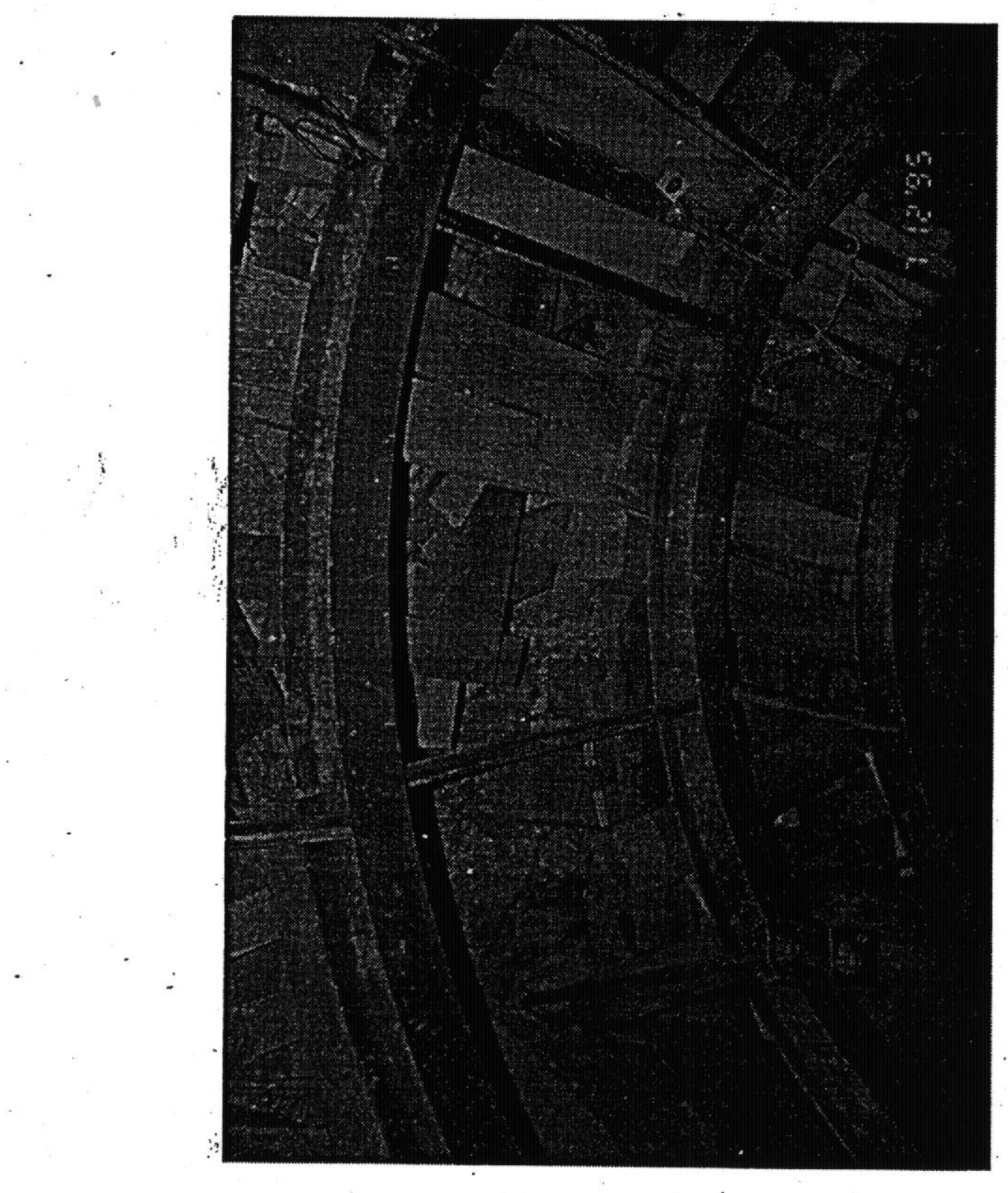

Figure 5. Lengths of $4 \times 4$ in. wood pieces have been used as fault fillings and for consolidation in areas of rock fall or displacement. 
the policy regarding material usage documentation, prohibitions on materials, and spill recovery in effect when the zone was

excavated and constructed. In the future this information will simplify the prediction of materials usage and aid the establishment of a smaller tolerance for error in the estimation of quantities of materials used during a potential repository construction phase.

\subsubsection{Impact of change in companies actually conducting the excavation.}

The contract to excavate and construct the tunnel has been subcontracted by REECo to Kiewit. The Materials Identification Characterization and Evaluation Sub-activity has not obtained TFM reports generated, by Kiewit. The impact of the transition from REECo to Kiewit on the types of data recorded and the state of data access is not yet known. However, the requirements have not changed. Therefore we expect that Kiewit has continued to follow existing procedures which require the submission of TFM reports.

\section{Model development}

\subsection{Examination of Potential Repository Designs.}

The development of an understanding of current repository designs and the preparation for drift scale materials modeling is addressed in MOL 126, 'Progress Report on the Development of Computer modeling modules'.

\subsection{Materials Database and Decision-making software.}

Preliminary assessment of decision-analysis software that will ultimately be used within the Integration Task to streamline experimental needs and computer modeling efforts.

A preliminary survey of the available software has lead to the choice of a simple decision analysis software, for the Macintosh, made by TreeAge Software, Inc., called - DATA ${ }^{\mathrm{TM}}(2.5)$ for initial assessment of needs in this area on a simple system before a major investment of time and money is made on more sophisticated software.

DATA $^{\mathrm{TM}}$ is a stand-alone application that can be linked to spreadsheets or databases in 
a two-way linkage. It surveys the other application for values (e.g. probabilities and/or payoffs) to be used in its calculations. It can also export its calculations (e.g. expected values, standard deviation values and path probabilities). DATA ${ }^{\mathrm{TM}}$ invokes Bayesian decision analysis. Its analytical features include one-way and two-way sensitivity analyses, threshold analysis, three types of probability distributions, Bayes revision, and Markov analysis. Up to four payoffs for each scenario can be assigned, thereby supporting multi-attribute analysis. Sensitivity analyses and probability distributions are exhibited graphically.

The possible chain of events are identified in a tree structure that specifies the sequence of events. DATA ${ }^{\mathrm{TM}}$ calculates the value of each possible chain of events giving appropriate weight to each possible outcome. The decision maker can evaluate each intermediate point on the decision tree and identify the sequence that will maximize value or minimize costs.

Another software package under consideration for future use is DataSmarts ${ }^{\mathrm{TM}}$. by Technology Corp., which is based on AI technologies, such as neural networks, machine learning and expert systems. It is designed to forecast trends, diagnose conditions, process signals, and classify and recognize patterns. It provides exploratory analysis, profiling, and reporting of variable contributions.

\section{Introduced Materials Task Integration}

Evaluation of concerns related to specific materials identified by this work and identification of activities that need to be initiated within the Introduced Materials task that correspond to the materials identified in this report.

As a result of this preliminary assessment, the following materials have been defined as significant for further study. Some elaboration on the issues and the activity that carries out work to define these issues is given below.

\subsection{Metals.}

It is clear that in the long term much chemical modeling work will be required for metals. However, the experimental basis for much of this modeling is expected to come from work already underway in Waste Package Design. Therefore the metals 
will only be identified and quantified and characterized at this point. Interfaces are biocorrosion and abiotic corrosion activities in both Waste Package Design and Introduced Materials, radionuclide transport activities in Integrated testing, chemical modeling activities in Geochemistry and Introduced Materials, and Performance. Assessment and Repository Design.

\subsection{Cement.}

At the moment the Fundamental Materials Task of the YMP International Program is responsible for all of the long term abiotic chemical and mechanical assessment of cementitious materials at elevated temperatures within the YMP. The Fundamental Materials Task is a finite program which ends in FY 96. Its intention has been to develop a thermodynamic database of solid phases that may be found in cementitious materials at elevated temperatures. This fills a gap in the present thermodynamic database that is available for the prediction of water chemistry. Results of this work will be incorporated into the Introduced Materials Task. Work related to the biodegradation of cement is also being conducted within the International Program, and is also a small scale, finite project that does not address interactions between materials. Any further work in either of these areas required by the project will need to be continued within the scope of the Introduced Materials Task.

\subsection{Water.}

Documentation of water usage is a complex problem. As stated above, the evaluation of water that remains in the repository setting is difficult to estimate. The ability to develop accurate estimates of water usage will depend to a large extent on the application. That is, it appears that estimates of water used for the expansion of Swellex ${ }^{\mathrm{TM}}$ rockbolts will probably be more accurate and precise than those for water

used for drilling, simply because a known quantity of water is usually required to inflate a rockbolt. The ability to estimate water retrieval will also bear heavily on the ability to obtain accurate estimates and will also be somewhat dependent on function. An additional layer of complexity is the evaluation of materials such as concrete 
which may act as water reservoirs. In the case of cementitious materials, some may be pre-cast (as in the case of invert sections) or may be cast in place. Evaluation of the introduction of water in each of these cases is different, because the water that will be introduced to the repository and the time during the thermal history that it will be available to the repository as water or water vapor will differ. Issues related to the introduction of water into a potential repository include hydrological, chemical, and microbiological effects.

\subsection{Cellulose.}

It is clear that cellulose materials do not appear explicitly in engineering drawings, and are commonly introduced as a result of unanticipated events. Only estimates can be obtained from documentation of usage. Issues related to the use of cellulose include colloid and microbiological effects.

\subsection{Polymers.}

Polymer usage is not explicit in engineering drawings. Only estimates can be obtained from documentation of usage. The accuracy of these estimates will depend on the materials. For example, in the final analysis it will probably be possible to better characterize volumes of PVC pipe than quantities of epoxy resin. Issues related to the use of polymers include biodegradation, the generation of colloids and the potential chemical reactivity of certain degradation products.

\section{Summary and Conclusions}

The major points of this report reflect the state of development of this subactivity. At this stage, the most efficient and economical strategy is to take a broad based point of view, rather than presenting a large number of detailed facts with no attempt at synthesis. Thus, we describe the creation of a sound structure and foundation of this study and the manner in which future work will be conducted. Perhaps most importantly, we begin by developing the tools that will define the point at which this sub-activity has completed its mission: these are tools to assess the state of knowledge that is achievable and to assess that which is necessary for the 
purposes of the Project. Specifically, we discuss the state of data access within the YMP, outline the work of this sub-activity and its place in the Yucca Mountain -Project, and use specific examples to illustrate the utility of certain types of information that will be gathered.

Much of the initial work of the Materials Identification Characterization and Evaluation Sub-activity depends upon the retrieval of large amounts of archived data from the Yucca Mountain Project. YMP procedural documents describe particular methods and channels through which this data should be retrievable. This work provides one of few present opportunities to assess the retrieval of data that has been archived by the YMP. In this report we contrast the appearance of data accessibility based on procedural documents to the actual experience of data. retrieval. In short, it appears that although a large effort is being spent on developing procedures to collect data and perhaps even in generating that data, any actual archived data within the Yucca Mountain Project is of limited utility due to the state of data access. To date, searches have retrieved far more procedural documents than data. We look forward to an improved state of access to archived data, given that, as time progresses, both the quantity of data, and the demand for it, will increase.

Routes of information retrieval other than archival work that have been explored include the first hand study of the ESF and interviews with on-site construction staff. These options, appear at first glance to be more time intensive than the retrieval of archived data. However, they promise to provide a more comprehensive understanding of materials usage that will ultimately be useful in extrapolating information from the ESF setting to the prediction of materials usage in a potential radioactive waste repository. In order to develop this predictive capability it is necessary to know not only estimated materials usage, but also to recognize patterns in which usage normal usage deviates from those estimates. For some materials, this will be accomplished by recognizing zones of usage within the ESF as defined by construction technologies, such as category of ground control. In this manner, not only can suites of associated materials that relate to a location and a particular choice of technology be defined, but ranges of options and flexibility 
within a chosen design or technology are recognized and defined. Special circumstances and compensation for geologic factors can be recognized and factored into predictions appropriately, rather than becoming part of a large and meaningless average number.

Available water usage data illustrates a number of the data evaluation methods that will be used. In the future it should be possible to further constrain estimates of the amount of water that remains on the site in both fluid and stored (e.g. cement) forms by obtaining better information on water retrieval. It is clear that water usage is by and large a function of excavation progress punctuated by a few events of excess water usage. Therefore, rather than averaging total water usage, it should be possible to establish an average water usage per meter (of roughly between 2 and $5 \mathrm{kl} / \mathrm{m}$ ) that can be modified by a statistical distribution of excess water events. The character of the statistical distribution will be determined by further monitoring of water usage in the ESF.

The interest in identifying, classifying and quantifying unknowns comes from the need to increase the degree of precision in estimates of materials usage, and to better define the point at which the refinement of data is complete. To these ends we distinguish between two types of unknowns. The first type is data that is . unknown but knowable. For this category of data we wish to define the point at which increased resolution is insignificant to the Yucca Mountain Project. The second type is data that cannot be estimated such as unpredictable events or irregular activities. For this category of data we wish first to determine the significance of the information and second whether bounding or statistical analyses can be used to bracket or characterize the information

In conclusion, it has become clear that the work of the Materials Identification Characterization and Evaluation Sub-activity is timely and important. This work is of fundamental importance to the efficient and economical operation of the Introduced Materials Task, and its ability to respond to the needs of Performance Assessment, Repository Design and Waste Package Design Areas of the Yucca Mountain Project. Similar work conducted on a previous facility did not provide 
the scope of evaluative and predictive tools that are being developed by this subactivity.

\section{References}

$\checkmark$

Authored Reports

West, K. A., 1988, Nevada Nuclear Waste Storage Investigations Exploratory Shaft Facility Fluids and Materials Evaluation. LA-11398-MS, Los Alamos National Laboratory.

\section{Yucca Mountain Documents}

Determination of Importance Evaluation (DIE) for Subsurface Exploratory Studies Facility, BAB000000-01717-2200-00005, Rev. 5, ICN 0.

Tracers, Fluids And Materials Data Reporting And Management, Procedure YAP-2.8Q

Tracers, Fluids And Materials (TFM) Database Status Report for the period January 1995 - March

- 1995. Planning and Control System Deliverable \# OE903, dated April 1, 1995. 
Appendix A

\begin{tabular}{|c|c|c|c|c|c|c|c|}
\hline \multirow[t]{2}{*}{2} & \multirow[t]{2}{*}{ Material } & \multirow[t]{2}{*}{ Qty } & \multirow[t]{2}{*}{ Location } & \multirow[t]{2}{*}{ Depth } & \multirow[t]{2}{*}{ Composition } & \multicolumn{2}{|c|}{ Disposition } \\
\hline & & & & & & Stays & Removed \\
\hline \multirow{6}{*}{ Water } & Water & $10.8 \mathrm{M} \mathrm{gal}$ & N. Portal Road/Pad & surface & Well J-13 & $x$ & \\
\hline & Water & $7.2 \mathrm{M} \mathrm{gal}$ & N. Portal Road/Pad & surface & Well J-13 & & $x$ (3 days) \\
\hline & Water & $1.2 \mathrm{M} \mathrm{gal}$ & $\begin{array}{l}\text { Rock/topsoil } \\
\text { Storage Road/Pad }\end{array}$ & surface & Well J-13 & $x$ & \\
\hline & Water & $1.7 \mathrm{M} \mathrm{gal}$ & North portal pad & $\pm 3680 \mathrm{ft}$ & water & $x$ & \\
\hline & Water & $112 \mathrm{~K}$ gal & Starter tunnel & $3684 \mathrm{ft}$ & water & & $\underline{x}$ \\
\hline & Water & $500 \mathrm{~K}$ gal & $\begin{array}{l}\text { Rock/topsoil } \\
\text { Storage Road/Pad } \\
\end{array}$ & surface & Well J-13 & & $x$ ( 3 days $)$ \\
\hline \multirow[t]{2}{*}{ Gases } & Oxygen & $1000 \mathrm{cu} \mathrm{ft}$ & North ramp starter tunnel & $0-200 \mathrm{ft}$ ramp & oxygen & & $x$ (1 day) \\
\hline & Oxygen & $1000 \mathrm{cu} \mathrm{ft}$ & North ramp starter tunnel & $0-200 \mathrm{ft}$ ramp & oxygen & & $x$ (1 day) \\
\hline \multirow[t]{12}{*}{ Metals } & Weld rod & $150 \mathrm{lbs}$ & North ramp starter tunnel & $0-200 \mathrm{ft} \mathrm{ramp}$ & E70 $\times \times$ electrodes & $x$ & \\
\hline & Weld rod & $500 \mathrm{lbs}$ & North portal pad & surface & E70XX électrodes & & $x$ (30 days) \\
\hline & Weld rod & $300 \mathrm{lbs}$ & North portal pad & surface & E70XX electrodes & $x$ & \\
\hline & $\begin{array}{l}4 \times 4 \text { welded wire fabric, } \\
5 \text { guage. }\end{array}$ & $3000 \mathrm{sq} \mathrm{ft}$ & North ramp starter tunnel & $0-108 \mathrm{ft}$ & A-185 steel & $x$ & \\
\hline & 8 in steel channel & $300 \mathrm{ft}$ & North ramp starter tunnel & $0-108 \mathrm{ft}$ & A-36 steel & $x$ & \\
\hline & 16 guage landing mat & $500 \mathrm{sq} \mathrm{ft}$ & North ramp starter tunnel & $0-108 \mathrm{ft}$ & sheet metal & $x$ & \\
\hline & \begin{tabular}{|l} 
SS-46 Rockbolt \\
$10 \mathrm{ft}$ split set \\
\end{tabular} & 100 ea & North ramp starter tunnel & $0-108 \mathrm{ft}$ & F-432 steel & $x$ & \\
\hline & $\begin{array}{l}\text { SS-46 Rockbolt } \\
8 \mathrm{ft} \text { split set } \\
\end{array}$ & 100 ea & North ramp starter tunnel & $0-108 \mathrm{ft}$ & F-432 steel & $x$ & \\
\hline & $\begin{array}{l}\text { SS-46 Rockbolt } \\
6 \mathrm{ft} \text { split set }\end{array}$ & 200 ea & North ramp starter tunnel & $0-108 \mathrm{ft}$ & F-432 steel & $x$ & \\
\hline & $\begin{array}{l}\text { SS-46 Rockbolt } \\
4 \mathrm{ft} \text { split set }\end{array}$ & 200 ea & North ramp starter tunnel & $0-108 \mathrm{ft}$ & F-432 steel & $x$ & \\
\hline & Rebar & $50 \mathrm{~K} \mathrm{lb}$ & North portal pad & $\pm 3680 \mathrm{ft}$ & Steel & $x$ & \\
\hline & Rock bolt & $4 \mathrm{~K} \operatorname{lin} \mathrm{ft}$ & North portal pad & $\pm 3680 \mathrm{ft}$ & Steel & $x$ & \\
\hline
\end{tabular}




\section{Appendix A}

\begin{tabular}{|c|c|c|c|c|c|c|c|}
\hline & \multirow[t]{2}{*}{ Material } & \multirow[t]{2}{*}{ Qty } & \multirow{2}{*}{$\begin{array}{c}\text { Location } \\
\end{array}$} & \multirow[t]{2}{*}{ Depth } & \multirow[t]{2}{*}{ Composition } & \multicolumn{2}{|c|}{ Disposition } \\
\hline & & & & & & Stays & Removed \\
\hline \multirow{5}{*}{$\begin{array}{l}\text { Metals } \\
\text { continued }\end{array}$} & Rock bolt & $6400 \operatorname{lin} \mathrm{ft}$ & Starter tunnel & $3684 \mathrm{ft}$ & Steel & $x$ & \\
\hline & Wiremesh & $17 \mathrm{~K} \mathrm{sq} \mathrm{ft}$ & Starter tunnel & $3684 \mathrm{ft}$ & Steel & $x$ & \\
\hline & Multiplate Arch & $148 \mathrm{~K} \mathrm{lb}$ & North portal pad & $\pm 3680 \mathrm{ft}$ & Steel & $x$ & \\
\hline & Wire Fence & $14 \mathrm{~K} \mathrm{sq} \mathrm{ft}$ & North portal pad & $\pm 3680 \mathrm{ft}$ & Steel & $\mathbf{x}$ & \\
\hline & $\begin{array}{l}3.5 \mathrm{ft} \text { Dewidrag } \\
\text { Rockbolt }\end{array}$ & 400 ea & North ramp starter tunnel & $0-108 \mathrm{ft}$ & A-722 steel & $x^{\cdot}$ & 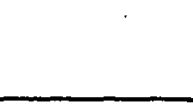 \\
\hline \multirow[t]{6}{*}{$\begin{array}{l}\text { Cellulose } \\
\text { Materials }\end{array}$} & Wooden forms & $600 \mathrm{sq} f t$ & $\begin{array}{l}\text { North portal access road } \\
\text { drain }\end{array}$ & surface & wood/steel & : & $x$ (8 days) \\
\hline & Wooden forms & $6000 \mathrm{sq} f \mathrm{ft}$ & North portal road & surface & wood/steel & : & $x$ (20 days) \\
\hline & $\begin{array}{l}2^{\prime \prime} \times 4^{\prime \prime} \times 8^{\prime \prime} \text { wooden } \\
\text { wedges }\end{array}$ & 1200 ea & North ramp starter tunnel & $0-108 \mathrm{ft}$ & Pine/fir & $x$ & \\
\hline & $\begin{array}{l}\text { Miscellaneous wood } \\
\text { blocking }\end{array}$ & $400 \mathrm{cu} \mathrm{ft}$ & North ramp starter tunnel & $0-108 \mathrm{ft}$ & Pine/fir & $x$ & . \\
\hline & $\begin{array}{l}8^{\prime \prime} \times 8^{\prime \prime} \times 20^{\prime} \text { support } \\
\text { timbers }\end{array}$ & 20 ea & North ramp starter tunnel & $0-108 \mathrm{ft}$ & Fir & 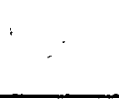 & $x$ (7 days) \\
\hline & Wooden forms & $2500 \mathrm{sq} f t$ & North ramp starter tunnel & $0-33 \mathrm{ft}$ & wood/steel & & $x(7$ days $)$ \\
\hline \multirow{10}{*}{$\begin{array}{l}\text { Misc. not } \\
\text { yet char- } \\
\text { acterized } \\
\text { substances }\end{array}$} & Blasting caps & 300 ea & North portal & surface & non-electric & & $x$ (3 days) \\
\hline & Explosive primer & $800 \mathrm{lbs}$ & North portal & $0-50 \mathrm{ft}$ & emulsion cartridge & & $x$ ( 3 days $)$ \\
\hline & Explosive primer & $200 \mathrm{lbs}$ & North portal & $0-50-\mathrm{ft}$ & $40 \%$ dynamite & . & $x$ (3 days $)$ \\
\hline & Primacord & 1000 lin. ft & North portal & surface & see MSDS prev. submitted; & : & $x(3$ days $)$ \\
\hline & Blasting caps & 2200 ea & North ramp starter tunnel & $0-200 \mathrm{ft} \mathrm{ramp}$ & Non-electric & & $x$ (3 days) \\
\hline & Explosive powder & $7610 \mathrm{lbs}$ & North ramp starter tunnel & $0-200 \mathrm{ft}$ ramp & Powder & . & $x(3$ days $)$ \\
\hline & Explosive trim powder & 2050 ea & North ramp starter tunnel & $0-200 \mathrm{ft}$ ramp & Trim powder & & $x$ (3 days) \\
\hline & Fire sealant & $5 \mathrm{cu} \mathrm{ft}$ & Switchgear bldg. & surface & ASTM E-815 & $x$ & \\
\hline & Fire caulking & $200 \mathrm{fl} \mathrm{oz}$ & Switchgear bldg. & surface & ASTM E-815 & $\mathbf{x}$ & \\
\hline & ANFO & $38 \mathrm{~K} \mathrm{lb}$ & North portal pad & $\pm 3680 \mathrm{ft}$ & MSDS & & $x$ \\
\hline
\end{tabular}




\section{Appendix A}

\begin{tabular}{|c|c|c|c|c|c|c|c|}
\hline & \multirow[t]{2}{*}{ Material } & \multirow[t]{2}{*}{ Qty } & \multirow[t]{2}{*}{ Location } & \multirow[t]{2}{*}{ Depth } & \multirow[t]{2}{*}{ Composition } & \multicolumn{2}{|c|}{ Disposition } \\
\hline & & & & & & Stays & Removed \\
\hline \multirow{9}{*}{$\begin{array}{l}\text { Misc. not } \\
\text { yet char- } \\
\text { acterized } \\
\text { substances } \\
\text { continued }\end{array}$} & Emulsion & $1500 \mathrm{lb}$ & North portal pad & $\pm 3680 \mathrm{ft}$ & MSDS & & $x$ \\
\hline & Trim explosive & $1500 \mathrm{lb}$ & North portal pad & $\pm 3680 \mathrm{ft}$ & MSDS & & $x$ \\
\hline & Det cord & $10 \mathrm{~K}$ lin $\mathrm{ft}$ & North portal pad & $\pm 3680 \mathrm{ft}$ & MSDS & & $x$ \\
\hline & Emulsion & $11 \mathrm{~K} \mathrm{lb}$ & Starter tunnel & $3684 \mathrm{ft}$ & MSDS & & $x$ \\
\hline & Trim explosive & $4.5 \mathrm{~K} \mathrm{lb}$ & Starter tunnel & $3684 \mathrm{ft}$ & MSDS & & $\underline{x}$ \\
\hline & Detonator & 3,500 ea & Starter tunnel & $3684 \mathrm{ft}$ & MSDS & & $x$ \\
\hline & Primacord & $10 \mathrm{~K}$ lin $\mathrm{ft}$ & North ramp starter tunnel & $0-200 \mathrm{ft}$ ramp & & & $x$ (3 days) \\
\hline & Polyphos 44 & $27 \mathrm{~K} \mathrm{fl} \mathrm{oz}$ & North portal Road/pad & $0-6 \mathrm{ft}$ & see previous MSDS & $x$ & - \\
\hline & Polyphos 44 & $3000 \mathrm{fl} \mathrm{oz}$ & $\begin{array}{l}\text { Rock/topsoil } \\
\text { Storage Road/Pad }\end{array}$ & $0-2 \mathrm{ft}$ & $\begin{array}{c}\text { see previous MSDS } \\
\therefore \\
\end{array}$ & $x$ & \\
\hline \multirow{6}{*}{$\begin{array}{l}\text { Cement } \\
\text { and } \\
\text { Cement } \\
\text { Additives }\end{array}$} & Bentonite clay & $50 \mathrm{cu}$ yds & North portal pad & $0-10 \mathrm{ft}$ & Bentonite & $x$ & \\
\hline & $\begin{array}{l}\text { Concrete curing } \\
\text { compound }\end{array}$ & $200 \mathrm{gal}$ & North portal pad & $0-5 \mathrm{ft}$ & ASTM C-309 & $x$ & \\
\hline & $\begin{array}{l}\text { Concrete curing } \\
\text { compound }\end{array}$ & $110 \mathrm{gal}$ & North ramp starter tunnel & $0-200 \mathrm{ft}$ & see MSDS & $x$ & \\
\hline & Concrete & 1000 cu yd & North portal pad & $\pm 3680 \mathrm{ft}$ & & $x$ & \\
\hline & $\begin{array}{l}\text { Concrete const. joint } \\
\text { sealant } \\
\end{array}$ & $10 \mathrm{gal}$ & Switchgear bldg. & surface & Elastomeric & $x$ & \\
\hline & Concrete: & 400 cu yd & Starter tunnel & $3684 \mathrm{ft}$ & Concrete & $x$ & \\
\hline \multirow{5}{*}{$\begin{array}{l}\text { Plastics/ } \\
\text { Polymers/ } \\
\text { Resins }\end{array}$} & Construction glue & $500 \mathrm{fl} \mathrm{oz}$ & Switchgear bldg. & $0-4.5 \mathrm{ft}$ & silicone & $\underline{x}$ & \\
\hline & Construction glue & $500 \mathrm{fl} \mathrm{oz}$ & Switchgear bldg. & surface & silicone & $x$ & \\
\hline & Liner glue & $50 \mathrm{gal}$ & Rock storage pad & surface & PVC & $x$ & \\
\hline & Pipe thread compound & $25 \mathrm{gal}$ & Switchgear bldg. & surface & Teflon & $x$ & \\
\hline & PVC cement & $50^{\circ} \mathrm{fl} \mathrm{oz}$ & Switchgear bldg. & 3 feet & PVC & $x$ & \\
\hline
\end{tabular}


Appendix A

\begin{tabular}{|c|c|c|c|c|c|c|c|}
\hline & Material & Qty & Location & Depth & Composition & $\overline{\mathrm{Di}}$ & osition \\
\hline . & & & . & & & Stays & Removed \\
\hline & Rockbolt resin & $7000 \mathrm{lbs}$ & North ramp starter tunnel & $0-200 \mathrm{ft}$ ramp & Dupont FasLoc & $x$ & $\cdot$ \\
\hline & Rockbolt resin & $3000 \mathrm{lbs}$ & North' portal & $0-20 \mathrm{ft}$ & Dupont FasLoc & $\underline{x}$ & \\
\hline $\begin{array}{l}\text { Plastics/ } \\
\text { Polymers/ }\end{array}$ & $\begin{array}{l}\text { Silicone caulking } \\
\text { compound }\end{array}$ & $500 \mathrm{fl} \mathrm{oz}$ & Switchgear bldg. & surface & ASTM C-920 & $x$ & \\
\hline Resins & $\begin{array}{l}2 " \text { thick foundation } \\
\text { insulation }\end{array}$ & $1800 \mathrm{sq} \mathrm{ft}$ & Switchgear bldg. & $0-4.5 \mathrm{ft}$ & Extruded polystyrene & $x$ & \\
\hline & Resin & $10 \mathrm{~K} \mathrm{lb}$ & Starter tunnel & $3684 \mathrm{ft}$ & MSDS & $x$ & \\
\hline & Acetylene & $500 \mathrm{cu} \mathrm{ft}$ & North ramp starter tunnel & $0-200 \mathrm{ft}$ ramp & hydrocarbons & & $x(1$ day $)$ \\
\hline & Acetylene & $500 \mathrm{cu} \mathrm{ft}$ & North portal road & surface & hydrocarbons & & $x$ (1 day) \\
\hline Hydro- & ANFO Explosive & $100 \mathrm{cuft}$ & North portal & $0-50 \mathrm{ft}$. & ammonium nitrate/fuel oil & & $x$ ( 3 days $)$ \\
\hline carbons & Cable pull lubricant & $250 \mathrm{gal}$ & Switchgear bldg. & $0-5 \mathrm{ft}$ & & $x$ & \\
\hline & Concrete form oil & $5 \mathrm{gal}$ & $\begin{array}{l}\text { North portal access road } \\
\text { drain }\end{array}$ & surface & hydrocarbons & . & $x$ (8 days $)$ \\
\hline . & Concrete form oil & $100 \mathrm{gal}$ & North portal road & surface & hydrocarbons & & $x$ (8 days) \\
\hline & Diesel Fuel & $200 \mathrm{~K}$ gal & N. Portal Road/Pad & surface & hydrocarbons & & $x$ (3 days) \\
\hline & Diesel Fuel & $50 \mathrm{~K}$ gal & $\begin{array}{l}\text { Rock/topsoil } \\
\text { Storage Road/Pad }\end{array}$ & surface & hydrocarbons & & $x$ ( 3 days) \\
\hline & Thread cutting oil & $100 \mathrm{gal}$ & North portal road & surface & hydrocarbons & & $x$ (1 day) \\
\hline & Concrete form oil & $5 \mathrm{gal}$ & North ramp starter tunnel & $0-33 \mathrm{ft}$ & $\therefore$ & & $x$ (7 days) \\
\hline Local & Fill Material & $137 \mathrm{~K}$ cu yd & North portal pad & $\pm 3680 \mathrm{ft}$ & aggregate & $x$ & \\
\hline Materials & & & & & & & \\
\hline
\end{tabular}




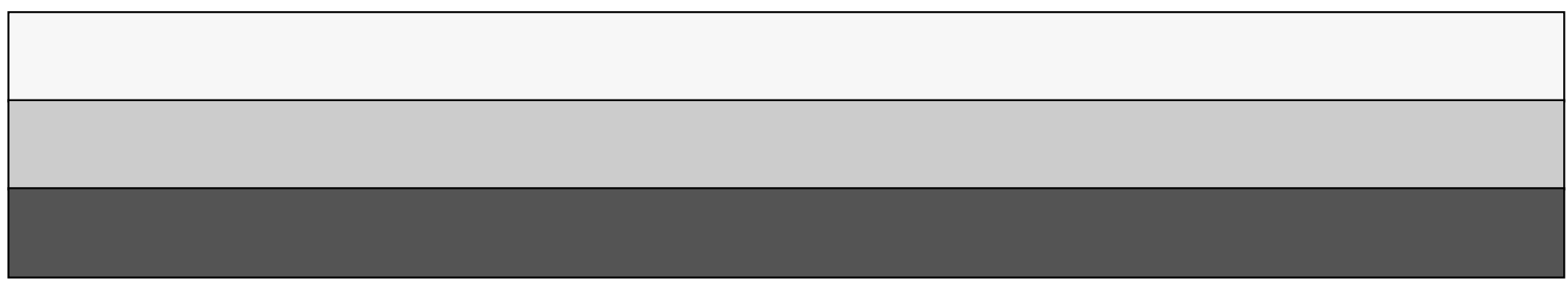

